\title{
$\longrightarrow$ AGUA YTERRITORIO \\ La tercera revolución del agua. Urbanización, gestión y contaminación del agua: El caso de Tepatitlán de Morelos, Jalisco, México, durante el siglo XX
}

\author{
The third water revolution. Urbanization, management and pollution of water: \\ The case of Tepatitlán de Morelos, Jalisco, México, during the XX century
}

Miguel A. Casillas-Báez

CIESAS, Guadalajara, México. miguelcasillasbaez@gmail.com

Resumen - En el presente trabajo hacemos una revisión al abastecimiento de agua en la ciudad de Tepatitlán en Jalisco, México, a lo largo del siglo XX y la primera década del siglo XXI. La gestión del agua se hacía al inicio del siglo XX usando aprovechamientos superficiales, como el río y los pozos superficiales. Mediante la política del Estado mexicano para concentrar población, fue necesaria la construcción de presas que almacenaran el agua suficiente para garantizar el abasto de una mayor población. Con la seguridad de agua, más habitantes eran atraídos por la ciudad, en un contexto geográfico de escasez de agua, puesto que se depende del aprovechamiento del agua de lluvia durante tres meses al año. Durante los últimos 20 años del siglo XX, con la dependencia del agua extraída desde pozos profundos, algunos con más de trescientos metros, la población modificó sus prácticas de tal forma que los escurrimientos de agua por los ríos y arroyos pasaron a ser los drenajes en la superficie. En el inicio del siglo XXI se consolida en la región una competencia por el agua con las grandes ciudades, pero también con la industria, la agricultura y la ganadería.

Abstract - In this paper, the water supply in the city of Tepatitlán in Jalisco, Mexico, is reviewed throughout the XX century and the first decade of XXI century. The management of water was made at the beginning of XX century from superficial exploitation, like rivers and superficial wells. Through the politics of Mexico to concentrate population, the construction of dams which keep enough water to guarantee the supply of greater population was necessary. With the security of water, more habitants were attracted by the city, in a geographical context of shortage of water, since it depends of use of rainwater during three months of the year. During the last 20 years of the XX century, with the dependence on water extracted from wells, some of them with more than 300 meters, the population modified their practices, so the water drainings by the rivers and streams became the drainage on the surface. At the beginning of the XXI century the region was consolidated for a competition for water, with the big cities, but as well with industries, agriculture and cattle raising.

Palabras clave: Abasto de agua, urbanización, contaminación, competencia regional

Keywords: Urban supply, urbanization, pollution, regional competition

Información Artículo: Recibido: 19 marzo 2012

Revisado: 10 diciembre 2012

Aceptado: 5 febrero 2013

Códigos JEL: 0, 033, 038, N9.

(c) Universidad de Jaén / Seminario Permanente Agua, Territorio y Medio Ambiente (CSIC) 